\title{
Konvergensi Media Baru dalam Penyampaian Pesan Melalui Podcast
}

\author{
Su Cin, Lusia Savitri Setyo Utami \\ sucin.915160212@stu.untar.ac.id,lusias@fikom.untar.ac.id
}

Fakultas Ilmu Komunikasi Universitas Tarumanagara

\begin{abstract}
Technology that is increasingly developing in favor of new media, podcast. Malamkliwon is a podcast with a mystical theme based on the experience of the broadcasts and podcasts listeners. In its distribution the Malamkliwon podcast announcer tells a story that has been packaged as interesting as possible through a media platform that is appropriate and close to the daily life of the community, besides the steps of collaborating with third parties to become another effort in reaching listeners. With the development of Malamkliwon podcast technology also uses the concept of new media convergence in the delivery of messages through podcasts. This research uses a descriptive qualitative method, while the theoretical basis used is mass communication and media convergence. The results showed three things related to media convergence according to Jenskin which was implemented by the Malamkliwon podcast inthe form of audio and visual take and then making the process of adding certain effects, then building good communication with listeners through social media Instagram nd the last direct message that is the content that will be raised to be brought in the podcast which can then the attract the listener's interest to listen until it's over. Media platforms that are utilized in message disguising are Spotify, YouTube and Instagram.
\end{abstract}

Keyword: podcast, media audio, media convergence, mass communication.

\begin{abstract}
Abstrak
Teknologi semakin berkembang mendukung adanya media baru yaitu podcast. Malamkliwon merupakan podcast yang mengangkat tema mistis berdasarkan pengalaman dari penyiar serta pendengar podcast. Dalam pendistribusiannya penyiar podcast Malamkliwon menyampaikan cerita yang telah dikemas dengan semenarik mungkin melalui platform media yang sesuai dan dekat dengan keseharian masyarakat. Selain itu langkah melakukan kolaborasi dengan pihak ketiga menjadi upaya lain dalam menjangkau pendengar. Dengan berkembangnya teknologi podcast, Malamkliwon juga menggunakan konsep konvergensi dalam penyampaian pesan. Penelitian ini bertujuan untuk mengetahui bagaimana konvergensi media baru dalam penyampaian pesan melalui podcast. Penelitian ini menggunakan metode deskriptif kualitatif. Landasan teori yang digunakan adalah komunikasi massa dan konvergensi media. Hasil penelitian menunjukkan tiga hal yang berkaitan dengan konvergensi media menurut Jenkins yang diterapkan oleh podcast Malamkliwon dalam upaya penyampaian pesan yaitu dengan pengolahan konten oleh penyiar berupa take audio maupun visual kemudian melakukan proses penambahan efek tertentu, selanjutnya membangun komunikasi yang baik dengan pendengar melalui sosial media Instagram dengan memberikan balasan terhadap komentar maupun direct message, terakhir yaitu isi konten yang akan diangkat untuk dibawakan dalam podcast dapat menarik minat pendengar untuk menyimak hingga usai.
\end{abstract}


Platform media yang dimanfaatkan dalam penyampaian pesan adalah Spotify, YouTube dan Instagram.

Kata kunci: podcast, media audio, konvergensi media, komunikasi massa.

\section{Pendahuluan}

Media merupakan sarana komunikator untuk menyampaikan pesan atau informasi kepada komunikan. Menurut Musfiqon (2012) dalam "Instructional Media and Technologies for Learning” mendefinisikan media merupakan saluran informasi yang menghubungkan antara sumber informasi dan penerima. Secara umum media dibagi menjadi tiga yaitu media visual, media audio dan media audio visual. Media ikut berkembang diiringi dengan perkembangan teknologi salah satu media baru yang mulai mendapatkan perhatian masyarakat adalah podcast, podcast merupakan singkatan dari ipod broadcasting yaitu merupakan aktivitas monolog antara dua orang atau lebih yang membicarakan sebuah tema atau topik tertentu dalam sebuah episode secara singkat podcast merupakan sebuah tulisan yang dikemas dalam bentuk sebuah rekaman audio kemudian didistribusikan dengan memanfaatkan berbagai jenis media, memiliki cara kerja yang sama dengan radio, podcast dapat diakses dengan memanfaatkan berbagai jenis platform.

Terdapat berbagai jenis alasan seorang individu mendengarkan podcast yaitu antara lain podcast dianggap fleksibel karena dapat diakses kapanpun dan dimanapun serta jenis konten yang disediakan sangat beragam, platform yang disediakan untuk menjadi pilihan masyarakat mendengarkan sebuah podcast antara lain Spotify, YouTube, Anchor, Google Podcasts, Apple Podcasts, SoundCloud, Pocket casts dan masih banyak lagi.

Alasan penulis melakukan penelitian ini adalah karena dengan maraknya podcast di Indonesia ternyata masih terdapat sebagian masyarakat yang merasa asing dengan podcast bahkan cenderung tidak mengenal podcast. Berdasarkan survei yang dilakukan oleh Dailysocial bekerjasama dengan JakPat Mobile Survey Platform pada tahun 2018 survei dilakukan kepada 2023 pengguna ponsel pintar terkait konsumsi podcast di Indonesia berdasarkan riset tersebut, sebanyak $67,97 \%$ responden mengenal podcast dan 32,03\% lainnya mengaku tidak familiar dengan podcast.

Sedangkan rentang usia pendengar podcast menurut survei Dailysocial adalah dibawah 16 tahun terdapat pendengar sebanyak 0,84\%, 16-19 tahun sebanyak 11,20\%, 20-25 tahun sebanyak 42,12\%, 26-29 tahun sebanyak 25,52\%, 30-35 tahun sebanyak 15,98\%, 36-39 tahun sebanyak 2,97\%, 40-45 tahun sebanyak $0,94 \%$ dan usia lebih dari 45 tahun sebanyak $0,45 \%$ dengan jenis kelamin pria sebanyak $57,09 \%$ dan wanita sebanyak $42,91 \%$. Dengan populasi pendengar di pulau jawa sebesar $80,57 \%$ dan yang terdapat di luar pulau Jawa sebanyak $19,43 \%$. 


\section{Gambar 1. pendengar} 2018

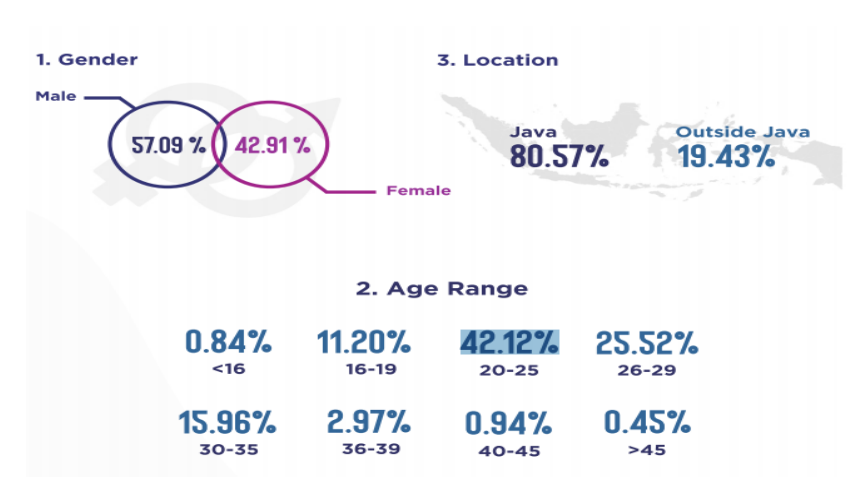

| DailySocialid
Survei podcast tahun

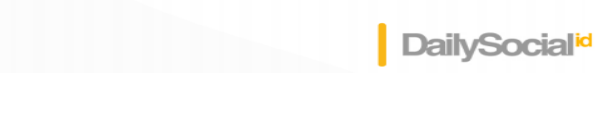

Sumber: DailySocial.com

Peneliti ingin mengetahui bagaimana cara penyiar melakukan konvergensi media dalam mendistribusikan podcast yang merupakan media audio baru kepada masyarakat melalui studi kepada podcast Malam Kliwon. Podcast Malam Kliwon menjadi salah satu podcast yang menarik banyak perhatian masyarakat dengan karakteristik dari masing-masing penyiar yang membawakan cerita bertema horror dengan memanfaatkan media sebagai platform dalam mendistribusikan podcast. Burke (2009) menyatakan bahwa istilah konvergensi mulai banyak digunakan sejak tahun 1990-an. Kata ini umum dipakai dalam perkembangan teknologi digital, integrasi teks, angka, gambar, video, dan suara.

\section{Metode Penelitian}

Peneliti menggunakan metode deskriptif kualitatif guna mendapatkan informasi secara mendalam untuk mengetahui bagaimana konvergensi media menjadi alat untuk melakukan distribusi podcast sebagai media audio baru kepada masyarakat. Teknik pengumpulan data yaitu wawancara, observasi, dan studi pustaka. Wawancara dilakukan terhadap informan pertama Ramadhanu Rizkinuriza sebagai pendiri sekaligus penyiar di podcast Malam Kliwon dan informan kedua Bimo Kusumo Yudo sebagai partner penyiar di podcast Malam Kliwon. Observasi dilakukan dengan melakukan pengamatan terhadap akun media sosial podcast Malam Kliwon dan mendapatkan informasi secara langsung dari informan. Terakhir, studi pustaka dilakukan oleh peneliti dengan memanfaatkan buku serta teori yang telah dipelajari dan karya ilmiah yang 
berkaitan dengan penelitian ini serta relevan sebagai sumber untuk melengkapi data yang diperlukan. Peneliti juga melakukan penelusuran data online.

\section{Hasil Penemuan dan Diskusi}

Podcast merupakan media berbasis audio yang menyajikan cerita yang dibawakan dalam bentuk audio. Namun podcast saat ini tidak hanya audio, tetapi dalam bentuk visual untuk mengakomodir pendengar podcast yang lebih tertarik melihat visual penyiar. Dengan tema yang menarik dan tidak membuat bosan pendengar, podcaster membuat sebuah podcast dapat menarik perhatian pendengar. Selain itu, cara bercerita seorang penyiar dan penggunaan kata yang sesuai dengan target pendengar membuat podcast mempunyai nilai lebih dimata pendengar. Podcast adalah sebuah cara untuk menikmati konten menarik yang bersumber dari seluruh dunia secara gratis dan mudah karena podcast saat ini telah banyak tersebar di berbagai platform media yang dekat dengan masyarakat sehingga memudahkan seseorang untuk mengaksesnya.

Menurut Grant dan Wilkinson (2010), konvergensi media membuat khalayak memiliki lebih banyak pilihan media dengan konten yang semakin beragam pula. Efek komunikasi massa yang dilakukan oleh penyiar podcast dalam mendistribusikan konten dikaitkan dengan teori menurut Liliweri yaitu :

1. Efek kognitif, dalam hal ini penyiar podcast berupaya mengubah pandangan pendengar bahwa acara dengan tema horror selalu dikemas dalam suasana yang menegangkan dan mencekam hingga akhir namun dengan pengemasan cerita yang berbeda oleh penyiar podcast membuat pandangan dan pengetahuan pendengar mulai beralih.

2. Efek afektif, pesan komunikasi massa mengakibatkan berubahnya perasaan tertentu dari pendengar dalam hal ini emosi yang berusaha diberikan oleh penyiar kepada pendengar adalah rasa senang, menghibur namun tidak menghilangkan suasana horror dalam cerita dengan penambahan efek back sound dalam podcast.

3. Efek konatif, efek ini merujuk pada perilaku nyata seperti tindakan, kegiatan, atau kebiasaan berperilaku, dalam hal ini kebiasaan berperilaku pendengar adalah menjadi rutin mengikuti setiap episode podcast baik dari YouTube maupun Spotify serta aktif dalam memberikan komentar ataupun memposting hal mengenai podcast di akun sosial media Instagram mereka.

Podcast Malam Kliwon melakukan hal yang serupa dalam dunia podcasting dengan penggunaan media yang dekat dengan keseharian masyarakat membuat pendengar dapat dengan mudah mengakses podcast. Selain itu, cerita yang dibacakan dalam podcast merupakan cerita pengalaman langsung dari pendengar podcast Malam Kliwon yang membagikannya melalui e-mail dan direct message Instagram, serta melakukan komunikasi secara baik kepada pendengar podcast selain itu pengolahan audio serta visual yang baik sehingga sampai kepada pendengar dengan baik pula. Konvergensi media oleh penyiar podcast Malamkliwon dalam menyampaikan pesan atau konten karena saat ini 
penggunaan teknologi media massa berkembang dengan baik. Hal ini dibuktikan dengan pengguna ponsel pintar yang semakin banyak sehinga kemungkinan seseorang tidak dapat mengakses ponsel pintar dapat dikatakan sangat sedikit.

Dengan pemanfaatan beberapa media dalam penyampaian pesan podcast oleh penyiar membuat konten podcast dapat dengan mudah sampai kepada pendengar yang telah tidak asing lagi dengan media sosial ini pula menjadi alasan pemilihan media yang dekat dengan masyarakat seperti Spotify, YouTube dan Instagram.

Awalnya podcast Malam Kliwon mendistribusikan konten pada tanggal 11 Juli 2019 dengan dibawakan oleh dua penyiar yang aktif dalam mendistribusikan konten. Penyiar tersebut memiliki motivasi serta pengalaman dalam dunia penyiaran atau audio sehingga membuat chemistry antara kedua penyiar sangat terasa dalam pembawaan cerita setiap episode podcast. Interaksi yang baik antara penyiar membuat chemistry terjalin sehingga membuat sebuah rekaman podcast menjadi menarik ketika sampai kepada pendengar, dengan penggunaan bahasa yang mudah dimengerti serta pemilihan kata yang tepat membuat pendengar merasakan kecocokan dengan sebuah podcast. Hal ini akan memunculkan sebuah kesetiaan terhadap podcast tersebut sehingga akan memicu pendengar untuk memberikan feedback berupa ikut serta membagikan cerita pengalaman atau memberikan komentar yang dapat membangun podcast menjadi semakin baik lagi.

Diawali dengan pengamatan yang dilakukan oleh Ramadhanu Rizkinuriza yang melihat bahwa awalnya podcast memang telah lama menjadi tren di Amerika dengan kiblat mayoritas masyarakat Indonesia yang tertuju pada negara bagian barat membuat tren yang terjadi disana juga perlahan ikut masuk di Indonesia. Di Indonesia, podcast mulai berkembang dengan baik ditandai dengan semakin bertambahnya podcaster yang rutin membagikan konten mereka dengan berbagai macam platform media. Podcaster tersebut juga berasal dari berbagai kalangan mulai dari selebriti maupun influencer. Setiap episode podcast Malam Kliwon dapat diakses melalui Spotify dan YouTube dengan kelebihan masingmasing media guna memenuhi keinginan pendengar yang mengharapkan sebuah podcast dengan tambahan visual atau hanya dengan mendengar audio saja. Selain kedua media tersebut terdapat pula media Instagram yang aktif dimanfaatkan oleh podcast Malam Kliwon untuk menjangkau pendengar.

Menurut Arief S. Sadiman,(2009), media audio adalah media untuk menyampaikan pesan yang akan disampaikan dalam bentuk lambang-lambang auditif, baik verbal (ke dalam kata-kata atau bahasa lisan) maupun non verbal. Berdasarkan hasil analisis bahwa penggunaan media oleh penyiar bertujuan untuk menjangkau pendengar sebagai upaya dalam melakukan pendistribusian podcast. Media Spotify merupakan platform media utama yang dijadikan sebagai media untuk mendistribusikan podcast kepada masyarakat. Saat ini Spotify menjadi pilihan masyarakat untuk mengakses hiburan seperti musik dengan adanya kanal khusus untuk podcast. Ini membuat pendistribusian podcast dapat dilakukan dengan lebih mudah. Sementara itu, pemanfaatan media YouTube oleh penyiar adalah sebagai media alternatif bagi pendengar yang menginginkan sebuah podcast dalam bentuk audio visual dengan tampilan visual ekspresi penyiar pada 
saat membawakan sebuah podcast. Pada permulaan podcast, Malam Kliwon mendistribusikan video menggunakan platform YouTube video yang akan ditayangkan di YouTube berdurasi 6-40 menit dengan waktu upload yaitu satu minggu 3-4 kali. Namun melihat antusiasme pendengar podcast yang mulai menggemari podcast dalam bentuk audio visual sehingga penyiar memutuskan untuk memberikan sebuah treatment baru untuk pendengar podcast yaitu dengan mulai menayangkan episode di akun YouTube podcast Malam Kliwon dengan durasi waktu sebuah video tidak lagi di tentukan oleh penyiar namun ditentukan oleh panjangnya cerita yang dibagikan oleh pendengar kepada penyiar yang akan dibawakan pada saat take. Namun sebelumnya cerita yang akan dibacakan telah disaring agar mendapatkan cerita yang menarik dan mempunyai keunikannya tersendiri. Selanjutnya Instagram digunakan oleh penyiar sebagai media untuk berkomunikasi kepada pendengar dengan memberikan balasan terhadap komentar yang diberikan pendengar di kolom komentar sebuah foto maupun video pada akun instagram podcast Malam Kliwon.

Pemanfaatan platform media Spotify,YouTube dan Instagram sebagai media yang dekat dengan masyarakat dan mudah untuk diakses menjadi alasan digunakannya secara aktif ketiga platform media ini sehingga memudahkan untuk menjangkau pendengar sebagai upaya mendistribusikan podcast. $\mathrm{K}$

egiatan lain yang dapat mendukung keberhasilan pendistribusian konten untuk sebuah podcast adalah melakukan sebuah kerjasama dengan pihak ketiga. Podcast Malam Kliwon melakukan kerjasama dengan akun Instagram tempat bercakap sebagai upaya untuk mendistribusikan konten horror namun dikemas dengan berbeda. Dengan cara bercerita yang dibawakan oleh penyiar serta penggunaan intonasi suara yang baik membuat pendengar dapat menjadi merasa nyaman ketika mendengarkan podcast. Podcast Malam Kliwon memiliki akses untuk membagikan cerita horror melalui Instagram TV tempat bercakap. Ketika podcast telah berhasil melakukan persuasi kepada pengikut yang terdapat pada media sosial tempat bercakap maka distribusi konten podcast telah berjalan dengan baik sehingga masyarakat pendengar podcast akan semakin bertambah dan membuat podcast semakin berkembang di Indonesia.

\section{Kesimpulan}

Konvergensi media yang dilakukan oleh penyiar dalam mendistribusikan podcast sebagai media audio baru memanfaatkan beberapa faktor yaitu penggunaan media dalam mendistribusikan podcast, chemistry antar penyiar, cara penyampaian cerita yang mudah dimengerti dan pemilihan kata yang tepat oleh penyiar ketika siaran, pengolahan konten yang baik serta segmentasi target yang sesuai dengan jenis konten, pemilihan nama pada podcast yang dapat membangun rasa ingin tahu dalam diri pendengar untuk mendengarkan podcast lebih dalam lagi, dan kerjasama yang baik dengan pihak lain yang dapat mendukung keberhasilan dalam penyampaian pesan kepada pendengar. Komunikasi intens yang dilakukan penyiar kepada pendengar melalui media sosial dapat membangun rasa kedekatan pendengar terhadap podcast sehingga dalam upaya melakukan distribusi podcast dapat berjalan dengan baik. Komunikasi massa yang 
memberikan efek kepada pendengar menjadi tolak ukur keberhasilan penyampaian konten penyiar kepada pendengar podcast.

\section{Ucapan Terima Kasih}

Dalam proses penulisan penulis menyadari mendapatkan banyak dukungan, bantuan serta bimbingan dari berbagai pihak, oleh karena itu pada kesempatan ini penulis ingin mengucapkan terima kasih kepada Tuhan Yang Maha Esa yang telah memberikan berkat dan rahmatnya kepada peneliti sehingga dapat menyelesaikan penelitian ini serta kepada pembimbing yang telah memberikan bimbingan dalam pembuatan jurnal ini serta keluarga yang telah memberikan banyak dukungan kepada penulis serta teman-teman yang tidak dapat disebutkan satu persatu.

\section{Daftar Pustaka}

Abdul Halik, (2013). Komunikasi Massa. Makassar: Alauddin University Press

Dominick dalam Elvinaro Ardianto. (2009) Komunikasi Massar Suatu Pengantar. Bandung: Refika Offset

Dyna Herlina, (2019) Literasi Media Teori dan Fasilitasi. Bandung : PT. Remaja Rosdakarya

Dudi Iskandar (2018) Konvergensi Media; Perbauran Ideologi, Politik, dan Etika Jurnalisme.Yogyakarta : ANDI

Joseph R, Dominick, (2017) The Dynamic of Mass Communication : Media Transition, New York : McGraw-Hill Companies.

Nurudin. (2007) Pengantar Komunikasi Massa. Jakarta: Cespur

Rulli Nasrullah. (2016) Media sosial : perspektif komunikasi, budaya, dan sosioteknologi. Bandung : Simbiosa Rekatama Media

Geoghegan, Michael W., Klass, Dan. (2007) Podcast Solutions: The Complete Guide to Audio and Video Podcasting. USA: Friendsof.

Terry Flew. (2008) New Media: An Introduction: Oxford University Press

Wahyu Wibowo. (2013) Kedaulatan frekuensi: regulasi penyiaran, peran KPI, dan konvergensi media. Penerbit Buku Kompas

Yudhi Munadi. (2012) Media Pembelajaran sebuah pendekatan baru. Jakarta : Gaung Persada Press

Cindy Yamaguchi. What is podcasting?, Media Specialist Office of Technology and Distance Learning University of Hawaii at Hilo. Terarsip di : https://hilo.hawaii.edu/oct/itus/documents/Podcasting.pdf

Dian Muhtadiah Hamna. (1 juni 2018) konvergensi media terhadap kinerja jurnalis (studi kasus: fajar tv dan fajar fm), Jurnal Tabligh Volume 19. Terarsip di : http://journal.uin-alauddin.ac.id/index.php/tabligh/article/download/5911/5112

Efi Fadilah, Pandan Yudhapramesti, Nindi Aristi. (2017) Podcast sebagai Alternatif Distribusi Konten. Kajian Jurnalisme, VOL .1(1),94-96, 2017. Terarsip di: http://jurnal.unpad.ac.id/kajian-jurnalisme/article/download/10562/6395

Farid Rusdi. (2017, April 21) Podcast Sebagai Industri Kreatif.Jurnal Komunikasi, APRIL 2017. Terarsip di : http://repository.untar.ac.id/460/1/1252-2953-1-PB.pdf 
Meisyanti, Woro Harkandi Kencana. (2020,Februari 2) Platform Digital Siaran Suara Berbasis On Demand (Studi Deskriptif Podcast di Indonesia). Jurnal Komunikasi dan Media,VOL.4(2),191-194, FEBRUARI 2020. Terarsip di: http://ejournal.upbatam.ac.id/index.php/commed/article/download/1547/1025

Indonesia Podcast, Siapa Pendengar Podcast di Indonesia. (2019 Agustus 15). Diakses pada 12 Februaru 2020 $\mathrm{http}$ //indonesiapodcast.com/siapa-pendengar-podcast-di-indonesia/

Podcast, Masa Depan Penyiaran yang Belum Pasaran di Indonesia. (2018 April 01) CNN Indonesia. Diakses pada 12 Februaru 2020 https://www.cnnindonesia.com/hiburan/20180401031240-241-287315/podcastmasa-depan-penyiaran-yang-belum-pasaran-di-indonesia

Surveri Laporan Dailysocial Pengguna Layanan Podcast 2018. (2018 Agustus 27) Dailysocial.com. diakses pada 12 Februari 2020 https://dailysocial.id/post/laporan-dailysocial-penggunaan-layanan-podcast-2018 